\title{
A voz e o silêncio em Paulo Henrioues Britto e Haroldo de Campos tradutores
}

\author{
Álvaro Faleiros \\ Universidade de São Paulo
}

Resumo

O intuito deste artigo é pensar modos como Paulo Henriques Britto e Haroldo de Campos lidam com suas próprias vozes e a voz do outro em suas traduções.

Résumé

Le but de cet article est de réfléchir sur des modes comment Paulo Henriques Britto et Haroldo de Campos travaillent leurs propres voix et les voix de l'autre dans leurs traductions.

\section{Palavras-chave}

Paulo Henriques

Britto;

Haroldo de Campos; tradução; voz.

Mots-clés

Paulo Henriques

Britto;

Haroldo de Campos; traduction

voix. 
Para pensar a relação entre as vozes de quem traduz e de quem é traduzido no poema, pareceu-nos que a experiência de poetas-tradutores seria especialmente profícua pelo fato de, necessariamente, nela estar em jogo a presença de uma voz poética do sujeito tradutor. Observando as traduções de poemas no Brasil, destacam-se alguns nomes de poetas tradutores, dentre os quais ganham relevo Haroldo de Campos e Paulo Henriques Britto por serem, talvez, dos reconhecidos poetas brasileiros, aqueles que mais refletiram sobre sua própria prática tradutória. Contrapor esses dois modos de enunciar mostrou-se revelador da complexidade envolvida nessa relação, apontando para implicações que lançam luz sobre a historicidade do traduzir. Como não se trata aqui de traçar uma evolução histórica, optamos partir da obra de Paulo Henriques Britto por ser ele o autor que buscou, em princípio, ao traduzir, um menor grau de interferência de sua própria voz no trabalho de tradução.

\title{
Paulo Henriques Britto e a poética do silêncio
}

Uma das imagens que Paulo Henriques Britto usa para para ilustrar o modo como pensa o lugar do tradutor na tradução é a da transparência. Em entrevista concedida aos Cadernos de Tradução, ${ }^{1}$ Britto, ao se contrapor ao que chama de "teorias feministas, desconstrutivistas, anticolonialistas etc.", afirma:

\begin{abstract}
Tendo travado conhecimento com todos os questionamentos que estão sendo feitos ao conceito de transparência, concordo que, de fato, o tradutor jamais pode ser transparente, que sua tradução sempre conterá marcas pessoais suas, que a postura de transparência pode até contribuir para a desvalorização do seu trabalho no mercado. No entanto, continuo achando que a minha meta, ao traduzir um texto literário, não pode ser outra que não tentar reproduzir no meu idioma, dentro das minhas possibilidades, os efeitos textuais do original. Ou seja: continuo querendo ser transparente, ainda que não tenha ilusões sobre a possibilidade de uma transparência absoluta. $^{2}$
\end{abstract}

Britto coloca explicitamente seu "desejo de transparência", querendo silenciar sua voz para que a voz do original possa ressoar. Sua consciência, contudo, da impossibilidade de se calar plenamente levou-o a elaborar uma reflexão para melhor qualificar a distinção entre uma voz que se colocaria na tradução daquela do poeta criador. Assim, um par de anos depois dessa sua entrevista, Britto escreve um importante artigo onde procura estabelecer algumas distinções entre escrita criativa e tradução. ${ }^{3}$ Nele, parte de sua experiência como tradutor e criador, apontando para o fato de que, quando traduz, seu desejo é aproximar-se do texto de partida enquanto, como criador, quando identifica a presença de outra voz, seu trabalho tende a querer distanciar-se dela para que seu texto torne-se mas autônomo. Ciente da complexidade envolvida nesses processos, esclarece que

\footnotetext{
em ambos os casos, há momentos de autonomização e de aproximação, mas enquanto na tradução a estrutura é mais ou menos equilibrada, no caso da criação o movimento de autonomização é claramente predominante. ${ }^{4}$
}

Aproximação e autonomização passam ser as balizas, cabendo à tradução aderir e à criação distanciar-se. O exemplo que utiliza para ilustrar o processo de autonomização é a escrita de seu poema intitulado "Pessoana". Ele esclarece que, como é comum em seu processo criativo, "o ponto de partida deste poema foi uma determinada estrutura verbal - no caso, dois versos"; os versos foram os seguintes: "Quando não sei o que sinto/ sei que o que sinto é o que 
sou". ${ }^{5}$ As contínuas reescritas do poema, todas insatisfatórias, acabaram levando-o ao seguinte terceto: "Mas se comigo coincido,/ de mim logo suspeito:/ sei que um dos dois é fingido"; sua escrita acabou revelando o seguinte:

\begin{abstract}
Tão logo acabei de escrever essa estrofe, senti que por trás dela estava o "comigo me desavim" o de Sá de Miranda. Mas esta constatação, por sua vez, chamou-me a atenção para o fato de que "fingido"vinha de "Autopsicografia"; curiosamente, foi a presença menos óbvia de Sáde Miranda que me fez perceber a outra presença, gritante, de Pessoa. ${ }^{6}$
\end{abstract}

Foram necessários mais dois anos para que ele chegasse a se descolar do texto de Fernando Pessoa. Chama atenção o fato de que seu próprio processo criativo só deslanchou, ganhando autonomia em relação às fontes, quando ele resolveu "impor uma forma bem restrita, para impedir que as ideias fluíssem naturalmente". A partir do momento em que restringiu a forma, "bastaram dois rascunhos para que chegasse [...] à forma final do poema".7

Como bem notou Augusto Massi na orelha de Trovar claro, "o poeta busca ideias de ordem diante do desconcerto do mundo". 8 A busca de ordem em Paulo Henriques Britto se dá, em geral, pela escolha de formas fixas, espécie de estrutura sobre a qual seu dizer o mundo se realiza. Em leitura que faz também de Trovar claro, Celia Pedrosa aponta para o fato de que, para Britto, "na busca de sua subjetividade lírica a necessidade existencial mais significativa é a busca da coerência", desse modo "sua poesia se constitui como clara e coerente reafirmação do jogo de máscaras, do truque de espelho, do lance de mágica que desmascara com convicção toda ilusão de onipotência, inclusive a sua própria". ${ }^{9}$ Pedrosa reconhece esse mesmo mecanismo no trabalho de Paulo Henriques Britto como poeta e como tradutor, assim, o que chama de "consciência clara do contraditório":

[...] Também pode ser identificada em sua recorrente opção pelo uso do que é em princípio já cristalizado como alheio, outro, disponível a uma manipulação onipotente e objetiva de leitor, como no texto a ser traduzido: formas clássicas fixas do soneto, da sextilha, da terça rima, a referência trovadoresca, a clareza discursiva do verso, nem um pouco experimental, a poesia de Fernando Pessoa e Casimiro de Abreu... ${ }^{10}$

Essa manipulação das formas passa também pela sua escolha dos textos a serem traduzidos, pois, provavelmente, a escolha não é aleatória. Ainda que possa ser influenciada por questões mercadológicas, por exemplo, sua publicação de uma antologia do poeta Wallace Stevens não é fruto do acaso. O próprio poeta reconhece que "traduzir foi primeiro uma maneira de dar continuidade a meu projeto de personalidade para uso próprio, só que utilizando sujeitos alheios para esse fim". ${ }^{11}$

Um caso interessante nesse sentido é justamente a tradução do poeta Wallace Stevens. Utilizando como fonte um texto mimeografado de Britto, Celia Pedrosa comenta que ele se interessou pelo poeta norte-americano devido a sua "combinação de arcabouço racional e abertura ao desconhecido". ${ }^{12}$ Entretanto, em seu texto "Tradução e criação", ele elabora sua relação com o Wallace Stevens partindo de outro ponto de vista; nele, o poema "Sunday Morning" ocupa o centro de sua argumentação. Britto o introduz da seguinte maneira:

A tradução deste poema de Wallace Stevens - da qual só examinarei aqui a primeira estrofe - foi iniciada em 1981, para meu próprio prazer, sem qualquer compromisso profissional; fiz duas versões em janeiro e março, e depois engavetei os rascunhos. [...] Cerca de cinco anos depois, porém, a Companhia das Letras encomendou-me 
uma antologia de Stevens, e ao mesmo tempo em que me pus a traduzir poemas adicionais resolvi retrabalhar os textos que havia tentado traduzir antes, inclusive "Sunday Morning"; assim, fiz várias mudanças na versão de março de 1981. ${ }^{13}$

O que entra em jogo para traduzir Wallace Stevens, segundo Britto, é o "prazer" e, posteriormente, as questões mercadológicas, criando um distanciamento que favorecerá seus argumentos a favor do silenciamento de sua própria voz no momento de traduzir. Após fazer uma síntese do tema tratado no poema e de sua forma, Britto comenta algumas de suas escolhas e hesitações na hora de traduzir, com o intuito de evidenciar que "há mudanças que parecem aproximar a tradução do original e mudanças que parecem afastá-la mais". ${ }^{14}$

Um dos exemplos que chama a atenção é o da tradução do verso 13 do poema, no qual se lê: "Stilled for the passing of her dreaming feet". Britto comenta que, em sua primeira versão, o verso foi traduzido por "Súbito lago a oferecer passagem"; na segunda versão, ele optou por "Súbito tornou-se lago a oferecer passagem". O tradutor também comenta ter percebido que "súbito" não correspondia a nada no original. Esse verso, na versão publicada, foi totalmente refeito, transformando-se em "Aquietou-se para dar passagem/ A seus pés sonhadores". O que interessa aqui é o fato de que

o verso inicial, de onde saiu a imagem do lago, que embora estranha ao original sobreviveu até a segunda versão, fora sugerido por um item lexical e um padrão rítmico extraídos de uma segunda fonte que não o poema de Stevens: o soneto de Fernando Pessoa, "Súbita mão de algum fantasma oculto", que me veio à mente durante a elaboração da tradução e por algum motivo se intrometeu no meu texto. ${ }^{15}$

Essa consciência reforçou seu desejo de aproximação com o texto-fonte, pois, para Britto, assim como ocorre com a forma fixa na hora em que escreve seus próprios poemas, na tradução, "a primeira fonte, ou original, exerce um efeito de controle sobre a tradução". Britto ainda comenta que:

Quando se dá a intromissão de uma segunda fonte, ela simplesmente é descartada se a aproximação a ela leva a uma autonomização excessiva com relação ao original: foi o que vimos no verso "Súbito lago a oferecer passagem". ${ }^{16}$

Assim, a consciência da intromissão e o controle exercido pelo texto-fonte, conclui Britto, "teve o efeito de fazer com que não restasse nenhum vestígio do verso inicial do soneto de Pessoa na versão final". ${ }^{17}$

\section{Haroldo de Campos e o coro paralelo}

A passagem supracitada vai na direção oposta ao que costuma afirmar o que é a tradução outro grande poeta brasileiro, Haroldo de Campos. Ao traduzir passagens do Fausto de Goethe em português, Campos se interessa justamente pelas possíveis ressonâncias de outras dicções. Conforme o autor:

A tradução é também uma persona através da qual fala a tradição. Nesse sentido, como a paródia, ela é também um "canto paralelo", um diálogo não apenas com a voz do original, mas com outras vozes textuais. Assim, ela se deixa derivar no movimento plagiotrópico geral da literatura [...]. O nosso Odorico Mendes, "pai do rococó" (Sousândrade) e patriarca da tradução criativa, interpolava, quando lhe parecia bem, em suas traduções homéricas, versos de Camões, Francisco Manuel de Melo, Antônio Ferreira, Filinto Elísio. $\mathrm{Na}$ recriação do "Coro dos Lêmures (Grablegung/ Enterramento)", usei deliberadamente de uma dicção cabralina, haurida no auto Vida e morte severina. ${ }^{18}$ 
No movimento plagiotrópico proposto, não interessa silenciar vozes alheias, mas fazêlas ecoar em coro no canto paralelo que se produz. É a reverberação das vozes que interessa, ou, como afirma Mauricio Mendonça Cardozo, ao tratar da escuta e da responsabilidade na relação com o outro em tradução,

\begin{abstract}
a ressonância (o tom, o timbre) pressupõe alguma forma de repercussão, um vibrar junto, uma participação (methexis). Como metáfora da construção de sentido, o sonoro evidenciaria, portanto, uma relação que não pode ser centrada apenas numa das partes, uma relação que só faz sentido enquanto repercussão, reverberação. Nesses termos, ouvir o outro presumiria, já de partida, uma outra forma de relação, marcada por uma abertura à interferência, à reverberação do outro em mim. ${ }^{19}$
\end{abstract}

$\mathrm{Na}$ passagem acima chama atenção o vibrar junto, que pode ser em ambas as direções. Não são apenas vozes alheias que ressoam na tradução, ou a voz do original que reverbera é também a voz, o corpo daquele que traduz, em sua historicidade. Caso interessante é o modo como repercutem as vozes na recepção de Mallarmé por Haroldo de Campos.

Como já apontei anteriormente, ${ }^{20} \mathrm{o}$ complexo enunciativo envolvendo a apropriação de Mallarmé pelos poetas concretos inicia-se com a presença daquele já nos primeiros manifestos. Dificilmente há algum artigo do grupo em que não figure o nome do poeta francês. Assim, em Plano-piloto para a poesia concreta", de 1958, Mallarmé (Coup de dés) já é citado como um de seus precursores, nomeando-o "o primeiro salto qualitativo: subdivisions prismatiques de l'idée; espaços (blanc) e recursos tipográficos como elementos substantivos da composição". ${ }^{21}$ Mas, antes, em "A obra de arte aberta", após apontar como "eixos radiais as obras de Mallarmé (Un coup de dés), Joyce, Pound e Cummings", Haroldo já havia enumerado motivos que o levaram a considerar Um lance de dados de Mallarmé um texto central para o movimento concretista:

A concepção de estrutura pluridividida ou capilarizada que caracteriza o poemaconstelação mallarmeano, liquidando a noção de desenvolvimento linear seccionado em princípio-meio-fim, em prol de uma organização circular da matéria poética, torna perempta toda relojoaria rítmica [...] que se apoie no hábito metrificante. ${ }^{22}$

O que se destaca aqui é a nova concepção rítmica em jogo no texto mallarmeano, isto é, sua ruptura com a linearidade sintagmática por meio da disposição tipográfica. Esse projeto é levado às últimas consequências, até o esgotamento, na poesia concreta. É o que afirma o próprio Haroldo de Campos, em 1997, quando, em seu artigo "Linhagem de Mallarmé no Brasil", lembra que o movimento concretista, com sua radicalização "verbo-voco-visual", chegou ao esgotamento do campo possível. Assim, "até a sensação do limite, a poesia concreta empenhou-se em levar até as últimas conseqüências o projeto mallarmeano". No mesmo texto, Haroldo sugere que, após esse esgotamento, restaria a "pós-utopia: a poesia da presentidade".

O presente não conhece senão sínteses provisórias e o único resíduo utópico que nele deve e pode permanecer é a dimensão crítica e dialógica que permanece na utopia. [...] A poesia pós-utópica do presente [...] tem, como poesia da agoridade, um dispositivo crítico indispensável na operação tradutória [que] - vista como prática de leitura reflexiva da tradição - permite recombinar a pluralidade dos passados possíveis e presentificá-los. ${ }^{23}$

Diante desse esgotamento, parece que uma saída possível passa a ser traduzir o próprio Mallarmé; é o que, em meados dos anos 1970, faz o grupo, cabendo a Haroldo de Campos a tradução de Un coup de dés para o português. A tradução do poema é feita por Haroldo pouco 
depois do citado esgotamento das possibilidades utópicas do poema realizado pelos concretistas. Entretanto, no momento em que o traduz, o que destaca não é mais a espacialidade do poema, como se lê no prefácio:

Mallarmé é um syntaxier exímio, um perito em elipses e arabescos, um reversor de ordens [...] Mas ei-lo também, espeleólogo-etimologista [...] perscrutando a raiz das palavras, para nelas ressoar cordas ocultas, amortecidas pelo uso idiomático, percuti-las, imantá-las de imprevistos revérberos [...]. "Efeitos de sintaxe", [...] "efeitos de etimologia" [...]. Efeitos sutis, delicadíssimos, duplo jogo de filigrana e abismo, onde tudo deve ser medido, mensurado, mentado, co-medido, co-mensurado, co-mentado.

A abordagem do tradutor distingue-se daquela do poeta concreto por uma preocupação com a sintaxe e com o que chama de "etimologia musical" e já não tanto com o tipográfico. Se é certo que Haroldo, quando traduz, está atento ao jogo tipográfico e grafo-numerológico do poema, cabe notar, contudo, que ele acrescenta a essas preocupações outras de ordem fonosemântica e sintática. Nesse sentido, as notas à tradução de Haroldo são bastante esclarecedoras, como quando comenta a tradução de gouffre.

FENESCIDO... ABISMO (FLÉTRIE... GOUFFRE) [...] Gouffre é o mesmo Abismo branco da pág. 3. "Vórtice" ou outra palavra sinônima não me dariam as rimas toantes como CIMO e feneSCIDO, que abISMO favorece. Adotei uma grafia caprichosa para feneSCIDO (ortograficamente, feneCido), a fim de ressaltar as vibrações conotativas. ${ }^{25}$

Como se pode notar, o que o motivou a tradução de gouffre por "abismo" foram justamente as potencialidades paranomásicas da palavra "abismo". A escolha de Haroldo de Campos é justificada pelo fato de as correspondências semântico-visuais imediatas serem altamente significantes na leitura que faz do poema. Sua "escolha caprichosa" da ortografia para "fenescido" (sic) condiz com uma possível leitura barroca de Mallarmé. Trata-se de leitura compartilhada com Deleuze, que também identifica traços barrocos em Mallarmé. Para o filósofo francês, "a dobra é, sem dúvida, a noção mais importante de Mallarmé, não somente a noção, mas, antes a operação, o ato operatório que faz dele um grande poeta barroco". ${ }^{26} \mathrm{O}$ procedimento de Haroldo de Campos consiste, pois, em implicar-se nas dobras mallarmeanas, reconhecendo nelas princípios que vão ajudá-lo a pensar e a produzir um neobarroco latino americano.

Haroldo de Campos o faz de modo explícito em seu "larvário barroquista" quando afirma que: a contribuição renovadora de Lezama e Sarduy se dá mais em nível frásico e transfrásico do que, propriamente na palavra enquanto matriz lexical codificada, ambos são primacialmente syntaxiers. ${ }^{27}$ Ao qualificar a poética deles Haroldo de Campos utiliza o mesmo termo que havia usado para descrever a escrita mallarmeana. O neobarroco surge assim como o movimento estético que permite a Haroldo de Campos deslocar-se da matemática verbovoco-visual da poesia concreta para a organicidade transfrásica do syntaxier; deslocamento que corresponde, em grande medida, ao próprio modo como concebe o ato de traduzir Mallarmé.

Ao analisar as operações textuais mobilizadas em Sarduy, Milton ${ }^{28}$ destaca a importância da intertextualidade, identificando em Sarduy dois grandes procedimentos, a saber: a citação, sobreposição de um texto em outro; e a reminiscência, quando o texto transposto funde-se no outro. Além disso, Milton descreve ainda quais seriam os elementos 
fonéticos, sêmicos e sintagmáticos intrínsecos à operação escritural de Sarduy. No que concerne à dimensão sonora, os mais relevantes seriam as metamorfoses fonéticas, como a aliteração e a paronomásia; quanto aos elementos sêmicos, destacam-se os que conduzem a significantes "reprimidos", de extração oral; os sintagmáticos, por sua vez, vão desde a inserção de uma obra em outra aos recursos da repetição e do espelhamento.

Como se pode notar, boa parte deles - metáforas poéticas, repetições, espelhamentos corresponde aos modos como Haroldo de Campos traduz Mallarmé, modo esse que confunde com sua própria poética. Em 1964, nesse mesmo momento em que o movimento da poesia concreta dava sinais de esgotamento, Haroldo de Campos publica os primeiros trechos de Galáxias, livro que conclui em 1984. Nele, Haroldo produz um texto pleno de "invasão de dobras, orlas iridescentes ou drapeados magníficos". ${ }^{29}$ Haroldo de Campos, aliás, nos anexos ao poema, define-o como "pulsão bioescritural em expansão galáctica". ${ }^{30}$ É essa galáxia que se irradia ao longo da reescrita de Un coup de dés. Desse modo, Haroldo de Campos não apenas introduz vozes alheias em traduções, como no caso da dicção cabralina, mas também faz com que sua sintaxe neobarroca conduza suas escolhas quando traduz Mallarmé, potencializando as dobras que habitam o poema mallarmeano.

Pode-se notar que o modo como sua própria voz atua é distinto: no primeiro caso, é por meio de uma "dicção cabralina" que ela atua; no segundo caso, é sua sintaxe neobarroca que se desdobra em Mallarmé, mas em ambos os casos há uma importante semelhança na postura que adota, uma atenção ao modo como o outro opera. E o mais surpreendente é que esse estado de atenção pode até levá-lo, por mais eloquente que seja, por vezes, a quase se calar.

\section{Silêncio, Haroldo}

Um dos primeiros a notar a plasticidade dos recursos tradutórios mobilizados por Haroldo de Campos foi Jorge Wanderley. Em seu estudo sobre sua poética de traduzir, comenta:

\footnotetext{
[...] A marca que distingue os concretos enquanto tradutores é que sua operação tradutora é capaz de NÂO ser radical, por mais radical que seja seu programa enquanto visão do literário; ou seja, por outras palavras: se são os componentes do grupo capazes de, no interior de um mesmo poema a traduzir, tomar caminhos diversos e até antagônicos, em operações que, NÃO RADICAIS, convivem com soluções obedientes a normas plurais, é exatamente esta capacidade de voltar-se sobre a própria norma - contrariando-a, fazendo com que varie, adaptando-a - que confere ao grupo concretista sua versatilidade. ${ }^{31}$
}

Essa versatilidade fez com que Haroldo de Campos, ao traduzir o poema L'infinito de Leopardi, deslocasse sua postura de syntaxier para dentro da poética de Leopardi, produzindo um texto que, em grande medida, corresponde àquilo que Paulo Henriques Britto considera o ideal de transparência cujo objetivo é reproduzir os "efeitos do texto original", como se pode notar: 
L'Infinito

Sempre caro mi fu quest'ermo colle

E questa siepe, che da tanta parte

Dell'ultimo orizzonte il guardo esclude

Ma sedendo e mirando, interminati

Spazi di làada quella, e sovraumani

Silenzi, e profondissima quiete

Io nel pensier mi fingo; ove per poco

Il cor non si spaura. E come il vento

Odo stormir tra queste piante, io quello

Infinito silenzio a questa voce

Vo comparando: e mi sovvien l'eterno,

E le morte stagioni, e la presente

E viva, e il suon di lei. Così tra questa

Immensitàmsi annega il pensier mio:

E il naufragar m'èldolce in questo mare.
Infinito

A mim sempre foi cara esta colina
deserta e a sebe que de tantos lados
exclui o olhar do último horizonte.
Mas sentado e mirando, intermináveis
espaços longe dela e sobre-humanos
silêncios, e quietude a mais profunda,
eu no pensar me finjo; onde por pouco
não se apavora o coração. E o vento
ouço nas plantas como rufla, e aquele
infinito silêncio a esta voz
vou comparando: e me recordo o eterno
e as mortas estações, e esta presente
e, viva, e o seu rumor. É assim que nesta
imensidade afogo o pensamento:
e o naufrágio é doce neste mar.

Andréia Guerini (2000), ao comparar as duas traduções, nota que Haroldo de Campos manteve não apenas o mesmo número de versos, mas o número exato de palavras, assim como a isometria, apenas deslocando-a dos "endecassílabos livres". Como se trata de aspectos formais caros ao tradutor brasileiro, nada aí surpreende. Entretanto, temos, nesse caso, apesar da opção por minúsculas em inícios de versos, a reprodução praticamente da mesma sintaxe, inclusive dos mesmos enjambements nos versos 4, 5 e 6; sendo, sintaticamente, a única alteração mais significativa a não manutenção das inversões nos versos $1,3,6,8$, 9, preferindo-se uma sintaxe mais direta em português. Em relação ao léxico, como bem nota Guerini, verificam-se apenas ajustes pontuais, de fato, apenas dois acréscimos — "esta" no verso 12 e "é" no verso 13 - e quatro supressões - "esta" no verso 2; "como" no verso 8; "meu" no verso 14; "me" no verso 15. ${ }^{32}$ A grande aderência de Haroldo de Campos ao poema de Leopardi leva Guerini a concluir que

\begin{abstract}
a tradução de Haroldo de Campos obedece ao princípio de respeitar quase na íntegra o tecido poético leopardiano. Assim, evidencia-se o conflito entre a concepç̃o teórica defendida por Haroldo de Campos e a sua prática de tradução. E uma boa tradução de poesia parece ser aquela que equilibra forma e conteúdo, como a do poema L'Infinito, realizada por Haroldo de Campos. Isso provavelmente acontece porque, neste caso, o tradutor e não transcriador, talvez movido por uma "afinidade eletiva", preferiu seguir mais a poética leopardiana que sua própria poética. ${ }^{33}$
\end{abstract}

Pode-se, contudo, pensar que o que está em jogo, para Haroldo de Campos, não seja, em sua prática, o princípio de que a transcriação implica, necessariamente, um distanciamento em relação ao texto de partida, ainda que, em casos como o de Mallarmé, a potencialização de um aspecto da poética possa de fato acrescentar considerável opacidade ao texto; o que parece interessar é a produção de um texto que opere por meio de princípios homólogos. É claro que, em caso de "afinidade eletiva", as possibilidades de fazer com que o outro vibre junto são maiores. 


\title{
Fala, Paulo
}

A "afinidade eletiva" talvez seja uma das razões pelas quais Paulo Henriques Britto tenha optado por escrever um comentário à autotradução que fez de seu soneto número $\mathrm{V}$, da série "Sete sonetos simétricos". O referido soneto, escrito no formato do soneto inglês, é o seguinte:

Surprised by what? Not necessarily by what a thing of beauty's supposed to be forever - Götterfunken kind of stuff.

No way. Lightning like this strikes (if at all) but once, and only when you're young enough, when you still have the spark, the wherewithal.

And yet, long past lo mezzo del camin, there're moments when it feels as if a pall of fog lifted, and a sight long unseen lay suddenly before your eyes. You say: It's that, again. Well, nearly that. I mean, as near as it gets, this late in the day.

Breathe in deep. The moment's not over yet.

And make a mental note: Not to forget.

Após realizar detalhada descrição dos aspectos métricos e acentuais do poema, Britto atenta para o fato de que seu "Soneto simétrico V" caracteriza-se pela presença de uma rede de citações. A primeira delas já se encontra no início do primeiro verso: "Surprised by what?", seria uma "citação truncada" 34 de um soneto pouco conhecido de William Wordsworth. Britto acrescenta que:

\begin{abstract}
As circunstâncias em que o soneto em questão foi escrito são relevantes. Wordsworth havia perdido uma filha com menos de quatro anos de idade, o que o deixara deprimido; tempos depois, num momento de intensa felicidade - momento em o poeta é surprised by joy, surpreendido pelo júbilo - ele se vira para o lado, que a intenção de compartilhar a alegria com a filha, e só então se lembra de que ela morreu. ${ }^{35}$
\end{abstract}

A segunda citação - que ocupa o final do verso 1, o verso 2 e o início do 3 -, por sua vez, faz referência à abertura de Endymion, do poeta romântico inglês, John Keats: " $A$ thing of beauty is a joy forever"; reescrito como: "Not necessarily/ by what a thing of beauty's supposed to bel forever". Ainda no terceiro verso, a palavra Götterfunken remete a "Freude, schöner Götterfunken", que é o verso inicial da "Ode an die Freude" de Schiller, frequentemente traduzida para o inglês como "Ode to Joy", e para o português como "Ode à alegria". Nas três citações, Britto destaca o fato de ter omitido a palavra-chave joy, apontando também para o fato de que a omissão transmitiria o "medo supersticioso de destruir essa efêmera sensação de alegria se a nomear". ${ }^{36}$ A quarta citação a que o autor-tradutor se refere encontra-se no sétimo verso e é o verso inicial do Inferno de Dante, o "meio do caminho", que remete à chegada a uma idade madura. Uma vez mais, joga-se com a ideia de como seria 
possível a experiência de uma alegria intensa a essa altura da vida. Trata-se, pois, de um poema que mobiliza múltiplas vozes, reestruturando-as em torno de uma matriz temática.

Ao autotraduzir seu soneto, Britto considerou que essa "rede de citações de poemas, mais ou menos conhecidos, que tem função estrutural em [seu] 'Soneto simétrico V' deveria ser recriada numa tradução que se pretenda fiel". A solução que elaborou foi a seguinte:

Será o pavão vermelho? Ora, direis, este raio não cai mais que uma vez no mesmo lugar - é a prova dos nove, é Götterfunken, uma coisa arisca sódada (e olhe lá!) a quem é) jovem, que ainda guarda em si uma faísca. Porém, passado o mezzo del camin, às vezes uma luz fraquinha pisca, e é como se sumisse uma neblina que há muito esconde uma paisagem bela. É ela, sim - pensa você - ali, na sua frente. Ou talvez a parte dela que ainda lhe cabe. Encha os pulmões de ar. Goze esse instante. Ele não vai durar. ${ }^{37}$

Uma comparação dos três primeiros versos do soneto em inglês surpreende imediatamente o leitor. Como seria possível traduzir "Surprised by what" por "Será o pavão vermelho"; ou ainda "Not necessarily/ by what a thing of beauty's supposed to bel forever Götterfunken kind of stuff” transmutar-se em "Ora, direis,/ este raio não cai mais que uma vez/ no mesmo lugar/ é a prova dos nove,/ é Götterfunken"? Para um adepto da transparência, em princípio, tais escolhas poderiam parecer desconcertantes, entretanto, Britto esclarece que,

quanto às citações de poetas ingleses, porém, decidi que faria mais sentido substituílas por outras de poetas lusófonos, que fossem reconhecíveis pelo leitor brasileiro pois não existem versões em português dos poemas de Wordsworth e Keats em questão que sejam amplamente conhecidas no Brasil. Do mesmo modo, era importante que tais citações fizessem referência à alegria, e que nelas a palavra "alegria" fosse suprimida, tal como ocorre em Surprised by joy. ${ }^{38}$

A escolha de "pavão vermelho" ao invés da citação de Keats logo na abertura do poema seria uma referência ao soneto de mesmo nome de Sosígenes Costa que, também na abertura de seu poema, o associa à alegria - "Ora, a alegria, este pavão vermelho". Essa citação pouco conhecida vem acompanhada de outra, de Olavo Bilac, "Ouvir estrelas"; mas como o poema de Bilac tem como tema o amor e não a alegria, Britto achou por bem multiplicar as vozes, acrescentando uma passagem do "Manifesto antropófago" - "A alegria é a prova dos nove" -, de Oswald de Andrade, também retomada por Gilberto Gil e Torquato Neto em "Geleia geral". Completa-se assim a tropicalização do soneto inglês, ao sabor de uma geleia geral. A argumentação de Britto nesse trecho difere pouco da de Haroldo de Campos quando justifica sua reescrita plagiotrópica do Segundo Fausto de Goethe.

Uma interpretação mais severa da postura de Paulo Henriques Britto apontaria para a aparente contradição entre seu discurso de transparência e sua prática, bem mais intrusiva. É o 
que faz, por exemplo, Rosemary Arrojo ao denunciar a "onipotência travestida de humildade" de Paulo Henriques Britto. Entretanto, avaliar aqui uma argumentação feita por Britto, em 2013, partindo de uma discussão feita quinze anos atrás, seria estar surdo ao movimento do próprio campo de ressonância do pensamento de Britto. Basta, como exemplo, retomar um artigo seu mais recente, "O tradutor como mediador cultural", no qual Britto aponta para o fato de que a tradução é um processo de mediação extremamente complexo "que necessariamente envolve um grau elevado de manipulação". ${ }^{40}$ No mesmo parágrafo, ele ainda acrescenta que, no extremo da manipulação, situa-se justamente a poesia, caso em que "não pode haver nenhuma pretenção de neutralidade"; o que o leva, logo em seguida, a concluir que se trata "de um terreno traiçoeiro em que é difícil justificar as opções feitas, em que a decisão tomada hoje pelo tradutor hoje pode muito bem ser rejeitada por ele próprio amanhã".

É nesse terreno movediço que as posições de fala vão se constituindo, levando, por vezes, à multiplicação das vozes, ou a arroubos timbrísticos e de tom, e por vezes, ao silêncio, abrindo o campo para algumas transparências. Nesse jogo de vozes e espelhos, parece importante não ser indiferente à complexidade do outro e do um, tornando a escuta mais atenta.

\section{Escuta}

Para entender as variações de postura adotadas por Haroldo de Campos e Paulo Henriques é necessário, para retomar Cardozo, ${ }^{41}$ considerar a natureza da relação que se estabelece em cada diálogo que os tradutores estabelecem com o original.

Assim, ao elaborar seu Fausto, Haroldo de Campos o faz de modo muito particular. Uma primeira observação do título de seu trabalho - Deus e o diabo no Fausto de Goethe -, ao qual se segue o nome do próprio Haroldo de Campos, aponta claramente para o caráter autoral dessa obra. Essa impressão se confirma ao abrir o livro, pois, temos imediatamente o Sumário onde se lê "FAUST (Johann Wolfgang von GOETHE)/ As duas cenas finais do SEGUNDO FAUSTO, transcriadas em português por Haroldo de Campos". Essa "primeira parte" do livro tem 66 páginas, e é seguida de uma "segunda parte", com 138 páginas, intitulada precisamente "DEUS E O DIABO NO FAUSTO DE GOETHE (Haroldo de Campos)" (sic); e que corresponde exatamente ao que se lê na capa do livro.

Desse modo, Haroldo de Campos deixa muito claro que seu livro é um ensaio de leitura de um trecho muito específico da obra de Goethe. Como vimos acima, é justamente na recriação do "Coro dos Lêmures (Grablegung/Enterramento)" que Haroldo de Campos opta por uma dicção cabralina; e precisamente sobre esse trecho ele diz: "será interessante referir aqui que meu procedimento, neste ponto, é absolutamente goethiano: o poeta do Fausto, no canto dos Lêmures, deixa passar ecos da canção dos coveiros, do V Ato do Hamlet de Shakespeare". ${ }^{42}$ Trata-se, pois, de recuperar um procedimento identificado em Goethe e de atualizá-lo.

A tradução de Mallarmé, por sua vez, ocupa um lugar bastante particular na obra de Haroldo de Campos. Deve-se lembrar que Haroldo de Campos é um poeta de vanguarda, autor de manifestos e de posturas muitas vezes veementes. Sua poética elabora-se, pois, por meio de afinidades e de filiações, cabendo a Mallarmé um lugar de destaque nesse processo de 
construção de sua própria voz. A tradução de Un coup de dés ocorre no momento em que o poeta brasileiro está explorando as possiblidades de uma dicção neobarroca, fazendo com que ressoassem amplificados os torneios mallarmeanos; por isso seus desdobramentos vibraram de modo tão intenso.

No caso de Leopardi, apesar de a voz de Haroldo de Campos ressoar de modo absolutamente distinto - uma vez que, como se pode notar, ele atua de modo muito mais silencioso -, o princípio que adota é o mesmo: identificar um procedimento e replicá-lo. Em seu ensaio no qual incluiu a tradução do poema L'Infinito, comenta que se trata de "composição de apenas 15 versos, agenciados por uma sábia técnica de cortes e tencionados por uma rigorosíssima seleção vocabular"; ${ }^{43}$ e mais adiante acrescenta que incluiu a tradução do poema para que o leitor pudesse apreciar "a modernidade de sua logopeia poética", explicando ser ela "a dança do intelecto entre as palavras". ${ }^{44}$ A tradução do poema na qual recupera cada um dos enjambements e mantém todos os substantivos e adjetivos do poema condiz com a leitura que faz do procedimento; mostrando-se, uma vez mais, atento a ele.

Paulo Henriques Britto, assim como Haroldo de Campos, também se coloca em estado de escuta. Em Wallace Stevens cala a presença mais reconhecível de seu Fernando Pessoa para dar voz ao texto-fonte, pois soou para ele ser este o melhor mecanismo para recuperar o que havia chamado de "combinação de arcabouço racional e abertura ao desconhecido". Já, ao traduzir seu próprio soneto inglês, Britto prefere operar como "mediador cultural" tropicalizando poetas ingleses numa "geleia geral" na qual convivem, entre outros, Oswald de Andrade, Gilberto Gil, Olavo Bilac e Sosígenes Costa. O grau de afinidade e familiaridade com o texto-fonte, do qual é autor, parece ter deslocado sua escuta, fazendo-o sensível a outras vozes que, em outros contextos, tende a silenciar.

O que se pode depreender da dinâmica que envolve as vozes e os silêncios produzidos por Haroldo de Campos e Paulo Henriques Britto tradutores, é que, em ambos os casos, os procedimentos aparentemente distintos, ressoam a partir de um mesmo lugar, que é justamente o da escuta; da capacidade de traduzir não a partir de uma forma aparente, mas de fazer ressoar um lugar de fala, um procedimento. Como aponta Mauricio Mendonça Cardozo, seguindo os passos de Jean-Luc Nancy:45 "escutar não é simplesmente ouvir", isto é, colocarse em estado de escuta é poder ler o que o movimento do outro implica. Daí a necessidade de uma ética da escuta em tradução,

\begin{abstract}
para apontar aqui na direção de uma responsabilidade da leitura, ler o outro em tradução, ao invés de um movimento marcado exclusivamente pela expectativa do encontro com um outro-eu, [...] reorienta-se, assim, como uma ética da nãoindiferença na leitura do outro em tradução: não in-diferença à nossa própria tendência de reduzir o outro a uma continuidade de nós mesmos; não indiferença à condição de recorte e assinatura de toda leitura; nãoindiferença ao trabalho de escuta que funda toda tradução. ${ }^{47}$
\end{abstract}

Escutar a vozes e os silêncios de Haroldo de Campos e de Paulo Henriques Britto, assim como as vozes que ressoam desde suas traduções, permite compreender que "a condição de recorte" aqui determina o alcance e a qualidade da relação que se estabelece entre as vozes do texto-fonte e as vozes dos tradutores. Assim, ao traduzir Goethe, Mallarmé ou Leopardi, Haroldo se mostra não indiferente à poética dos autores. As leituras que propõe do outro, contudo, dependem do modo como os outros o continuam - Goethe abre espaço a sua 
plagiotropia; Mallarmé permite explorações barrocas da sintaxe; Leopardi leva à logopeia das vanguardas, todos campos caros a Haroldo de Campos, em sua potência e singularidade. A assinatura de Paulo Henriques Britto, por sua vez, aponta para seu desejo de coerência e controle, num jogo de máscaras e espelhos elaborado por proximidade e distanciamento em relação a suas fontes, como no caso de Fernando Pessoa e de Wallace Stevens; e que corresponde ao modo como opera sua própria poética.

No início deste artigo justificamos nossa escolha pelo fato de Haroldo de Campos e de Paulo Henriques Britto serem dois poetas de destaque no sistema literário brasileiro, o que faz com que suas traduções correspondam ao que Meschonnic chamou de traduções ativas, ou seja, aquelas em que há um "encontro de vozes". ${ }^{48}$ Nesse encontro se produz uma ética e uma política do traduzir, que é também uma ética da voz; uma ética entendida como "a busca de um sujeito que se esforça para se constituir como sujeito por sua atividade". ${ }^{49}$ Assim, esse esforço de constituição de um sujeito é também o de constituição de uma voz, de uma identidade. Vale, por fim, lembrar, ainda com Meschonnic que "a identidade não deve se opor a uma alteridade, mas a identidade só advém pela alteridade, o que faz a invenção de sua própria historicidade". ${ }^{50}$ Assim, a tradução se constitui como um espaço privilegiado de escuta, onde é possível acessar modos como os outros e nós ressoamos, numa constante constituição de vozes; vozes que só escutamos e situamos se pudermos, também, atentar para seus silêncios.

\section{Notas de fim}

${ }^{1}$ Paulo Henriques Britto, “Entrevista”, Cadernos de Tradução, no. 2, Florianópolis, 1997, p. 468.

2 Idem.

3 Paulo Henriques Britto, “Tradução e criação”, Cadernos de Tradução, no. 4, Florianópolis, 1999.

${ }^{4}$ Idem.

${ }^{5}$ Idem, p. 248.

${ }^{6}$ Idem.

${ }^{7}$ Idem, p. 250.

${ }^{8}$ Augusto Massi, “Orelha” in Paulo Henriques Britto, Trovar claro, São Paulo, Companhia das Letras, 1997.

${ }^{9}$ Celia Pedrosa, "Poética do olhar na contemporaneidade", Literatura e Sociedade, no. 8, São Paulo, 2005 , p. 95.

${ }^{10}$ Idem, ibidem

${ }^{11}$ Apud Pedrosa,"Poética do olhar na contemporaneidade", op. cit.

12 Idem, p. 95.

${ }^{13}$ Britto, "Tradução e criação", op. cit., p. 243.

14 Idem, p. 245.

15 Idem, p. 246

16 Idem, ibidem.

17 Idem, p. 247.

${ }^{18}$ Haroldo de Campos, Deus e o diabo no Fausto de Goethe, São Paulo, Perspectiva, 1992, p. 191.

19 Mauricio Mendonça Cardozo "Escuta e responsabilidade na relação com o outro em tradução", Outra Travessia, no. 15, Florianópolis, 2013.

20 Cf. Álvaro Faleiros, "Haroldo de Campos e a dobra de Mallarmé", Anais XI Congresso Internacional da ABRALIC - Tessituras, Interaçoes, Convergếncias, 2008. Disponível em:' http://www.abralic.org.br/download/anaiseventos/cong2008/AnaisOnline/simposios/pdf/065/ALVARO_FALEIR OS.pdf. Acesso em 23 fev. 2015.

21 Augusto de Campos; Décio Pignatari; Haroldo de Campos, Teoria da poesia concreta: textos críticos e manifestos 1950-1960, São Paulo, Edições Invenção, 1965, pp. 156-158.

22 Idem, p. 28.

${ }^{23}$ Haroldo de Campos, "Poesia e modernidade: da morte da arte à constelação. O poema pós-utópico" in $O$ arcoíris branco, Rio de Janeiro, Imago, 1997, pp. 243-269:. 
24 Stéphane Mallarmé, Mallarmé, organização, tradução e notas de Augusto de Campos, Décio Pignatari e Haroldo de Campos, São Paulo, Perspectiva, 1991

${ }^{25}$ Idem, p. 139.

${ }^{26}$ Gilles Deleuze, Le pli, Paris, Minuit, 1988, p. 83.

${ }^{27}$ Haroldo de Campos, "Poesia e modernidade...", op. cit., p. 193.

${ }^{28}$ Heloísa Costa Milton, "Barroco e neobarroco" in Eurídice Figueiredo (org.), Conceitos de literatura e cultura, Juiz de Fora/ Niterói, Editora UFJF/ EdUFF, 2005, pp. 70-93; 77-78.

${ }^{29}$ Néstor Perlongher, Caribe transplatino, São Paulo, Iluminuras, 1991, pp. 13.

${ }^{30}$ Haroldo de Campos, Galáxias, São Paulo, 34 Letras, 2004.

31 Jorge Wanderley, A tradução do poema - Notas sobre a experiência da geração de 45 e dos concretos, dissertação de mestrado, PUC-Rio, 1983, g

32 Andreia Guerini, “'L'Infinito’: Tensão entre teoria e prática na tradução de Haroldo de Campos”, Cadernos de Tradução, no. 6, Florianópolis, 2000, p. 112.

${ }^{33}$ Idem, ibidem.

${ }^{34}$ Paulo Henriques Britto, “Uma experiência de autotradução”, Philia\&Filia, vol. 2, no. 1, Porto Alegre, 2013 , p. 64.

35 Idem, ibidem.

${ }^{36}$ Idem, ibidem.

${ }^{37}$ Idem, ibidem.

${ }^{38}$ Paulo Henriques Britto, "Tradução e criação", op. cit., p. 68.

39 Rosemary Arrojo, "O tradutor 'invisível' por ele mesmo. Paulo Henriques Britto entre a humildade e a onipotência", Trabalhos em Linguística Aplicada, no. 36, Campinas, 2000.

40 Paulo Henriques Britto, "O tradutor como mediador cultural", Synergies Brasil, no. especial 2, São Paulo, 2010, p.

41 Cardozo, "Escuta e responsabilidade", op. cit.

42 Campos, Deus e o diabo no Fausto de Goethe, op. cit., p. 292.

${ }^{43}$ Haroldo de Campos, "Leopardi, teórico da vanguarda" in A arte no horizonte do provável, São Paulo, Perspectiva, 1979, p. 186.

${ }^{44}$ Idem, p.192.

45 Jean-Luc Nancy, À l'écoute, 2002.

46 Cardozo, "Escuta e responsabilidade", op. cit., p. 29.

47 Idem

48 Henri Meschonnic, Éthique et politique du traduire, Paris, Verdier, 2007, p. 142.

49 Idem, p. 8

50 Idem, p. 9. 